\title{
IDENTIFIKASI KANDUNGAN KLOROFIL GENUS PIPER (SIRIH) SEBAGAI KANDIDAT FOOD SUPPLEMENT
}

\author{
Identification of Chlorophyll Content in Genus Piper (Sirih) as Food Supplement Candidate
}

\author{
Khoirin Maghfiroh \\ Prodi Ilmu dan Teknologi Pangan, Fakultas Pertanian, Universitas Yudharta Pasuruan \\ Email : ri2nkhoir@gmail.com
}

\begin{abstract}
Chlorophyll in the higher plants physiology can be chlorophyll A and chlorophyll B. One of the higher plants that have limited benefit from the medication is Piper. Functionally, the chlorophyll in the Piper can be used as a food supplement that is using physiology systems in the human body. Some among were blood systems, digestive systems and immune systems. The aim of this study is to know the chlorophyll contents of the genus Piper that can be used as a food supplement by identification the quantity of chlorophyll A, chlorophyll B and total amount chlorophyll based on the color of leaf, as well as to know the quantity of chlorophyll A, chlorophyll $B$ and total amount chlorophyll based on different species. The study was being conducted which weighted $2 \mathrm{~g}$ sample, and then was refined by mashed. The samples that have been mashed must be extracted with acetone $85 \%$. Analyzing of chlorophyll content in Piper was using a spectrophotometer. Then, the data than contains of Chlorophyll was analyzed by one way (ANAVA), then the data were analyzed by BNT analysis. Based on the result of the study was indicate that the quantity of Chlorophyll A on Piper betle L. old leaves is 74,57 ppm and the quantity of Chlorophyll B on Piper betle L. young leaves is 39,75 ppm. Furthermore, the highest total quantity of the chlorophyll on Piper betle L. old leaves is 109,31 ppm.
\end{abstract}

Keywords : chlorophyll, piper, food supplement

\begin{abstract}
ABSTRAK
Klorofil pada tumbuhan tingkat tinggi secara fisiologi dapat berupa klorofil A dan klorofil B. Salah satu tumbuhan tingkat tinggi yang pemanfaatannya masih terbatas pada pengobatan adalah Sirih. Klorofil pada tanaman Sirih secara fungsional dapat dimanfaatkan sebagai food supplement. yang mampu menstimulasi sistem - sistem fisiologi di dalam tubuh. Beberapa di antaranya adalah sistem peredaran darah, pencernaan dan pertahanan tubuh (imun). Tujuan penelitian ini adalah untuk mengetahui kandungan klorofil tanaman genus Piper yang dapat dijadikan sebagai kandidat food supplement melalui identifikasi jumlah klorofil A, klorofil B dan klorofil total berdasarkan warna daun serta untuk mengetahui jumlah klorofil A, klorofil B dan klorofil total berdasarkan perbedaan spesies. Penelitian dilakukan dengan menimbang $2 \mathrm{~g}$ sampel, kemudian dihaluskan dengan penumbukan. Sampel yang telah dihaluskan, diekstrak dengan aseton $85 \%$. Analisa kandungan klorofil ekstrak tanaman Sirih menggunakan spektrofotometer. Data kandungan klorofil dianalisa menggunakan analisis varians (ANOVA) one way yang dilanjutkan dengan uji BNT. Berdasarkan hasil penelitian menunjukkan bahwa jumlah klorofil A tertinggi terdapat pada daun tua tanaman Sirih Hijau (Piper betle L.) sebesar 74,57 ppm dan jumlah klorofil B tertinggi terdapat pada daun muda tanaman Sirih Hijau (Piper betle L.) sebesar 39,75 ppm. Sedangkan jumlah klorofil total tertinggi terdapat pada daun tua tanaman Sirih Hijau (Piper betle L.) sebesar 109,31 ppm.
\end{abstract}

Kata kunci : klorofil, piper, food supplement 


\section{PENDAHULUAN}

Klorofil merupakan media dalam fotosintesis. Sebagian besar klorofil tersebar pada organ daun. Reaksi fotosintesis memerlukan klorofil dan cahaya untuk menghasilkan energi. Bahan baku dalam reaksi fotosintesis berupa karbondioksida dan air. Hasil reaksi kedua senyawa tersebut menghasilkan karbohidrat dan oksigen, yang disebut sebagai energi dalam reaksi fotosintesis. Reaksi fotosintesis terjadi dalam sel. Bagian sel yang terlibat dalam reaksi fotosintesis adalah kloroplas. Terdapat dua bagian dalam kloroplas yang berperan untuk fotosintesis, yaitu grana dan stroma. Grana terdiri dari tumpukan granum yang berperan dalam reaksi terang. Sedangkan stroma memiliki peran dalam reaksi gelap (Nio Song dan Banyo, 2011). Cahaya berperan penting dalam fotosintesis. Perbedaan spektrum cahaya dapat mempengaruhi laju fotosintesis. Laju fotosintesis dapat mempengaruhi biosintesis klorofil. Tumbuhan antar spesies dalam satu genus memiliki biosintesis yang berbeda beda. Hal tersebut dipengaruhi oleh gen yang terdapat pada masing - masing spesies. Gen tersebut mengendalikan enzim yang berperan dalam biosintesis tetrapirol yang merupakan salah satu struktur klorofil (Handoko, dan Yunie 2013; Kurniawan, dkk., 2010). Biosintesis klorofil pada membran tilakoid berupa klorofil A dan B. Biosintesis klorofil B berasal dari klorofil A. Seiring dengan tingkat per-tumbuhan tanaman, terutama pada organ daun, biosintesis klorofil B mengalami peningkatan (Maulid, dan Ainun, 2015).

Klorofil merupakan salah satu metabolit sekunder yang terdapat pada semua tanaman. Jumlah metabolit sekunder dalam bahan pangan dapat mengalami perubahan pasca pengolahan. Perubahan tersebut dapat disebabkan oleh berbagai jenis proses pengolahan bahan pangan yang kurang tepat. Hal tersebut dapat mengakibatkan penurunan jumlah metabolit sekunder pada bahan pangan. Beberapa proses pengolahan yang mengakibatkan berkurangnya jumlah metabolit sekunder adalah penghancuran, pemotongan dan pemanasan (Kusuma dan Nuri, 2012; Muhamad, dkk., 2015). Penurunan jumlah metabolit sekunder dapat mengakibatkan berkurangnya nilai gizi pada bahan pangan. Zat gizi dalam bahan pangan berperan penting untuk menstimulasi seluruh aktivitas sistem fisiologi dalam tubuh (Departemen Gizi dan Kesehatan Masyarakat FKUI. 2007).

Berbagai jenis stimulator telah dikembangkan untuk meningkatkan aktivitas sistem fisiologi di dalam tubuh. Stimulator dapat dikembangkan dalam bentuk obat - obatan (pharmaceutical) dan food supplement (nutraceutical). Beberapa sektor medis dan industri bahan pangan saat ini telah memanfaatkan Food supplement. Hal tersebut didukung oleh peresepsi konsumen yang saat ini cenderung mem-butuhkan produk yang memiliki banyak manfaat dalam tubuh. Manfaat tersebut berupa nilai kesehatan dan konvensional (Panday, dkk., 2010). Salah satu tanaman yang pemanfaatannya telah meluas dalam bidang pengobatan adalah tanaman yang berasal dari genus Piper (Sirih). Beberapa di antaranya, Sirih hijau (Piper betle L.) dan Sirih merah (Piper crocatum) telah dimanfaatkan sebagai bahan antibakteri, penurunan kadar glukosa, dan kolesterol, aktivitas antioksidan serta sistem pertahanan tubuh (Suliantari, dkk., 2012; Shinta dan Sudyanto, 2016; Hermiati dkk. 2013; Nugroho, 2012). Tanaman pada genus Piper selain mengandung berbagai metabolit sekunder yang memilki manfaat kesehatan, tanaman tersebut juga mengandung klorofil. Klorofil merupakan metabolit sekunder yang dapat dimanfaatkan sebagai food supplement. Klorofil yang bersumber dari Mikroalga telah dimanfaatkan sebagai pigmen pewarna alami bahan pangan, stimulasi pertumbuhan jaringan, antioksidan dan antimutagenik (Hosikian dkk., 2010). Klorofil dapat berperan dalam kesehatan dan nutrisi. Secara luas klorofil telah dimanfaatkan untuk pangan tambahan, 
pewarna bahan pangan, nutraceutical dan farmasi (Bishop, dan Heidi, 2012).

Berdasarkan hal tersebut, perlu dilakukan optimalisasi potensi tanaman Sirih dengan memanfaatkan tanaman tersebut sebagai food supplement. Tujuan dalam penelitian ini adalah untuk mengetahui kandungan klorofil tanaman genus Piper yang dapat dijadikan sebagai kandidat food supplement melalui identifikasi jumlah klorofil A, klorofil B dan klorofil total berdasarkan warna daun serta untuk mengetahui jumlah klorofil A, klorofil $\mathrm{B}$ dan klorofil total berdasarkan perbedaan spesies.

\section{METODE PELAKSANAAN}

\section{Preparasi tanaman sirih}

Tanaman Sirih yang digunakan dalam penelitian ini berasal dari daun muda dan daun tua spesies Piper betle L. Serta daun yang berasal dari daun tua spesies Piper crocatum. Sebelum dilakukan ektraksi, tanaman sirih disortasi atau dilakukan pemilihan. Selanjutnya, daun dicuci dengan air mengalir..

\section{Ekstrak tanaman sirih}

$2 \mathrm{~g}$ daun tanaman Sirih dari masing masing sampel yang telah dicuci, dihancurkan dengan mortal martil. Selanjutnya, daun dimasukkan dalam gelas kimia. Kemudian masing - masing sampel direndam dengan $500 \mathrm{ml}$ aceton $85 \%$ selama 1 x 24 jam. Selanjutnya sampel difiltrasi.

\section{Analisa Spektrofotometri}

'Sampel yang telah difiltrasi, dirunning dengan spektrofotometri. Masing - masing sampel diambil $1 \mathrm{ml}$. Selanjutnya, sampel dianalisa pada spektrofotometri pada panjang gelombang $663 \mathrm{~nm}$ dan $645 \mathrm{~nm}$.

\section{Analisa statistik}

Data kandungan klorofil A, B dan total klorofil yang telah diperoleh, diuji menggunakan ANOVA one way dengan selang kepercayaan 5\%. Kemudian dilanjutkan dengan uji BNT untuk untuk mengetahui tingkat signifikansi antar perlakuan.

\section{HASIL DAN PEMBAHASAN}

Berikut merupakan data hasil pengamatan kandungan klorofil pada Genus Piper :

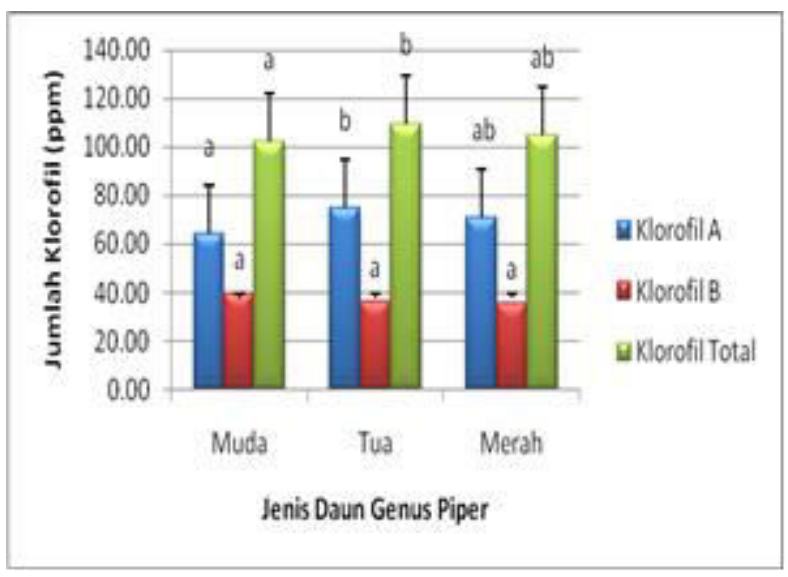

Gambar 1. Kandungan klorofil Genus Piper

Berdasarkan data jumlah klorofil genus Piper, diketahui bahwa jumlah klorofil A pada daun muda tanaman Sirih Hijau (Piper betle L.) sebesar 63,97 ppm meningkat secara siginifikan dengan jumlah klorofil A pada daun tua tanaman Sirih Hijau (Piper betle L.) sebesar 74,57 ppm. Namun keduanya tidak berbeda secara siginifikan dengan jumlah klorofil A pada daun Sirih Merah (Piper crocatum) sebesar 70,93 ppm. Jumlah klorofil B pada daun muda tanaman Sirih Hijau (Piper betle L.) sebesar 39,75 ppm tidak meningkat secara siginifikan dengan jumlah klorofil B pada daun tua tanaman sebesar Sirih Hijau (Piper betle L.) sebesar 36,39 ppm dan keduanya tidak berbeda secara siginifikan dengan jumlah klorofil B pada daun Sirih Merah (Piper crocatum) sebesar 35,77 ppm.

Selain kedua jenis klorofil tersebut, juga dilakukan analisa terkait jumlah klorofil total untuk mengetahui jumlah klorofil secara keseluruhan yang digunakan dalam fotosintesis. Berdasarkan hasil analisa data jumlah klorofil total, diketahui bahwa 
klorofil total daun muda tanaman Sirih Hijau (Piper betle L.) sebesar 102,10 ppm meningkat secara siginifikan dengan jumlah klorofil total daun tua tanaman Sirih Hijau (Piper betle L.) sebesar 109,31 ppm. Namun, keduanya tidak berbeda secara siginifikan dengan jumlah klorofil total daun Sirih Merah (Piper crocatum) sebesar 105,10 ppm.

Berdasarkan data hasil penelitian menunjukkan bahwa kadar klorofil total berdasarkan warna daun menunjukkan perbedaan. Perbedaan tersebut dapat disebabkan oleh beberapa faktor, salah satu di antaranya cahaya yang dapat mempengaruhi laju fotosintesis (Handoko, dan Yunie, 2013). Klorofil A dan B memiliki daya absorbsi tinggi terhadap pigmen biru dan ungu, jingga dan merah namun memiliki daya absorbs rendah terhadap pigmen hijau dan kuning hijau (Nio Song dan Banyo, 2011). Laju fotosintesis dipengaruhi oleh cahaya, unit klorofil dan rasio klorofil A dan B (Baker dan Hardwick, 1974). Data total klorofil dari ketiga sampel tersebut didominasi oleh klorofil A. hal tersebut diduga adanya proses pembentukan klorofil B oleh klorofil A dalam reaksi fotosintesis. Pembentukan klorofil A maupun B dikendalikan oleh prekursor pembentuk kedua klorofil tersebut. Reaksi pembentukan klorofil A maupun B dikendalikan oleh protoporfirin dan enzim - enzim yang terlibat dalam reaksi reduksi oksidasi. Selain itu, diduga disebabkan oleh adanya konversi dari gugus metil yang dimiliki klorofil A ke gugus formil / metanoil (aldehid) yang dimilik oleh klorofil B. Setiap klorofil yang disintesis dalam kloroplas terdiri dari klorofil A dan B. Pembentukan 1 klorofil membutuhkan 8 molekul 5-aminolevulinic acid. Secara struktural molekul tersebut terletak di posisi akhir rantai. Sedangkan gugus metal dan formil berada pada posisi 3 (Wettstein, dkk., 1995).

Perbedaan spesies merupakan salah satu faktor yang mempengaruhi kadar klorofil. Setiap spesies memiliki gen spesifik. Berdasarkan hasil pengamatan dari 36 spesies dari genus Piper, menunjukkan bahwa terjadi perbedaan yang siginifikan berdasarkan urutan antar spesies (Chaveerach dkk. 2016). Gen tersebut mengendalikan enzim yang berperan dalam biosintesis tetrapirol yang merupakan salah satu struktur klorofil (Handoko, P. dan Yunie F. 2013; Kurniawan, dkk. 2010). Klorofil memiliki pigmen tetrapirol yang dapat dikembangkan sebagai agen fotosensitizer. Aktivitas agen fotosensitizer dapat dipengaruhi oleh lingkungan dan sifat sensitizer tersebut. Salah satunya, $\mathrm{pH}$ asam dapat menyebabkan degradasi pada klorofil (Budiyanto, 2008). Gen, hormon, dan lingkungan merupakan faktor yang saling berkaitan dalam reaksi fotosintesis. Hal ini dapat mempengaruhi jumlah klorofil yang dihasilkan dalam reaksi tersebut. Klorofil sebagai salah satu metabolit sekunder dapat dijadikan sebagai kandidat food supplement. Berdasarkan data hasil pengamatan, dari kedua spesies tanaman Sirih berpotensi sebagai kandidat food supplement, sehingga perlu dilakukan optimalisasi potensi tanaman tersebut. Optimalisasi potensi tanaman secara aplikatif melalui food supplement yang dapat diolah kemudian diproduksi dalam berbagai bentuk, seperti kapsul, tablet, serbuk dan beberapa bentuk yang lain (Fretes, dkk, 2012; Suparmi dan Achmad, 2009).

\section{KESIMPULAN}

Berdasarkan warna daun diketahui bahwa kandungan klorofil tertinggi terdapat pada daun warna hijau tua tanaman Sirih hijau ((Piper betle L.) sebesar 74,57 ppm. Selain itu kandungan klorofil pada daun hijau muda dan tua tanaman Sirih serta tanaman Sirih merah didominasi oleh klorofil A. Berdasarkan variasi spesies, kandungan klorofil tertinggi pada tanaman Sirih hijau (Piper betle L.) sebesar 109,31 ppm.

\section{DAFTAR PUSTAKA}

Baker, N R dan K Hardwick. (1974). A model for the development of 
photosynthetic units in cocoa leaves. Proceedings of the Third International Congress on Photosynthesis, Rehovot. Elsevier, Amsterdam pp 1897-1906

Bishop W M dan Heidi M Z. (2012). Evaluation of Microalgae for use as Nutraceuticals and Nutritional Supplements. J Nutr. Food Sci. 2 (5)

Budiyanto Aji Wahyu. (2008). Pengaruh pengasaman terhadap Fotodegradasi Klorofil a. Jurnal Matematika dan Sains 13 (13)

Chaveerach A, Tawatchai T, Arisa S, Pansa A, dan Runglawan S. (2016). Efficient DNA barcode regions for classifying Piper species (Piperaceae). PhytoKeys 70: $1-10$

Departemen Gizi dan Kesehatan Masyarakat FKUI. (2007). Gizi dan Kesehatan Masyarakat. PT Raja Grafindo Persada. Jakarta

Fretes H.D, A B Susanto, Budhi P, dan Leenawaty L. (2012). Karotenoid dari Makroalgae dan Mikroalgae: potensi kesehatan aplikasi dan bioteknologi. $J$. Teknologi dan Industri Pangan XXIII (2)

Handoko P dan Yunie F. (2013). Pengaruh Spektrum Cahaya Tampak terhadap Laju Fotosintesis Tanamn Air Hydrilla verticillata. Proceeding Seminar Nasional X Pendidikan Biologi FKIP UNS

Hermiati, Rusli, Naomi Y M, Mersi S S. (2013). Ekstrak daun sirih hijau dan merah sebagai antioksidan pada minyak kelapa. Jurnal Teknik Kimia USU 2 (1)

Hosikian A, Su Lim, Ronald H, dan Michael K D. (2010). Chlorophyll extraction from microalgae: a review on the process engineering aspects. International Journal of Chemical Engineering . ID 391632

Kuniawan, Madha, Munifatul Izzati, Yulita Nur Chayati. (2010). Kandungan klorofil, karotenoid, dan vitamin c pada beberapa spesies tumbuhan akuatik. Buletin Anatomi dan Fisiologi XVIII (1)

Kusuma R.A dan Nuri A. (2012). Aktivitas Antioksidan Ekstrak Buah Takokak (Solanum torvum Swartz.). Skripsi. Institut Pertanian Bogor.

Mauled R R dan Ainun N L. (2015). Kadar Total Pigmen Klorofil dan Senyawa Antosianin Ekstrak Kastuba (Euphorbia pulcherrima) Berdasarkan Umur Daun. Proceeding Seminar Nasional Konversi dan Pemanfaatan Sumber Daya Alam FKIP UNS.

Muhammad P H, Luh Putu W, dan A A M Dewi Anggreni. (2015). Pengaruh suhu dan lama curing terhadap kandungan senyawa bioaktif ekstrak etanol bunga kecombrang (Nicolaia speciosa Horan). Jurnal Rekayasa dan Manajemen Agroindustri 3 (4)

Nio Song Ai dan Yunia Banyo, (2011). Konsentrasi klorofil daun sebagai indikator kekurangan air pada tanaman. Jurnal Ilmiah Sains Universitas Sam Ratulangi Manado 11(2)

Nugroho Y A. (2012). Efek pemberian kombinasi buah sirih (Piper betle L.) fruit, daun miyana (Plectranthus scutellarioides (L.) R.BR.) leaf, madu, dan kuning telur terhadap peningkatan aktivitas dan kapasitas fagositosis sel makrofag. Media Litbang Kesehatan 22 ( 1)

Panday M, Rohit K V dan Shubhini A S. (2010). Nutraceuticals: New Era of Medicine and Health. Asian Journal of Pharmaceutical and Clinical Research 3 ( 1)

Shinta D Y dan Sudyanto. (2016). Pemberian air rebusan daun sirih merah (Piper crocatum Ruiz\&Pav) terhadap kadar glukosa dan kolesterol darah mencit putih jantan. Journal of Sainstek 8(2) : 180-185 
Suliantari, Betty S L, Jenie dan Maggy T S. (2012). Aktivitas antibakteri fraksi fraksi ekstrak sirih hijau (Piper betle L.) terhadap patogen pangan. $J$. Teknologi dan Industri Pangan XXIII (2)

Suparmi dan Achmad S. (2009). Mengenal potensi rumput laut: kajian pemanfaatan sumber daya rumput laut dari aspek industri dan kesehatan. Majalah Ilmiah Sultan Agung 44: 118

Wettstein D V, Simon G dan C G Kanangara. (1995). Chlorophyll biosynthesis. The Plant Cell 7: 10391057 